DOI https://doi.org/10.30525/978-9934-26-173-2-56

\title{
ВИКОРИСТАННЯ ІННОВАЦІЙНИХ ТЕХНОЛОГІЙ В ФОРМУВАННІ ЗВ'ЯЗНОГО МОВЛЕННЯ У ДІТЕЙ ІЗ ТЯЖКИМИ ПОРУШЕННЯМИ МОВЛЕННЯ
}

\author{
Ольховська І. П. \\ вчитель-логопед \\ Комунальний заклад «Багатопрофільний навчально-реабілітаційний \\ иентр «Довіра» Криворізької міської ради \\ м. Кривий Ріг, Дніпропетровська область, Украӥна
}

Підвищення ефективності корекційної логопедичної роботи з усунення порушень мовлення у дітей з особливими освітніми потребами на даний момент є однією з актуальних проблем логопедії та спеціальної психології. На сучасному етапі розвитку суспільства кількість дітей, які мають мовленнєві порушення, збільшилася порівняно 3 попереднім десятиліттям і має тенденцію до подальшого зростання. Тому особливу увагу зосереджено на застосуванні у корекційній роботі психокорекційних технологій, що обумовлено специфікою мовленнєвих порушень і станом емоційно-вольової сфери дітей з мовленнєвою патологією. Ці порушення викликають труднощі в спілкуванні з оточуючими і у подальшому призводять до певних змін особистості, що відбивається на процесі подальшого навчання. Перебуваючи на межі зіткнення педагогіки, медицини, психології, нейролінгвистики, логопедія використовує найбільш ефективні методи та прийоми суміжних наук, адаптує їх до своїх потреб, що допомагає оптимізувати роботу вчителялогопеда. Використання в корекційній роботі різноманітних логопедичних технологій, що включають нетрадиційні методи та прийоми, запобігає втомі дітей, підтримує у дітей 3 різною мовленнєвою патологією пізнавальну активність, підвищує ефективність логопедичної роботи в цілому. Впровадження інноваційно-логопедичних технологій (ІЛТ) сьогодні є новою сходинкою у освітньому процесі. Основна мета полягає в гармонійному поєднанні сучасних інноваційних технологій з традиційними засобами розвитку дітей.

ІННОВАЦІЙНІ ТЕХНОЛОГІЇ В ЛОГОПЕДІЇ:

- арт-терапевтичні технології;

- сучасні технології логопедичного і пальцевого масажу;

- сучасні технології сенсорного навчання ;

- тілесно орієнтовані техніки;

- Су-Джок терапія; 
- інформаційно-комп'ютерні технології;

ІКТ (інформаційно-комп'ютерні технології)

Сучасне життя неможливо уявити без комп'ютера. Комп'ютери швидко увійшли в наше життя. Інтерес дитини до комп'ютера великий i справа дорослого направити його в потрібне русло. На даний час розробляється все більше і більше комп'ютерних логопедичних ігор, завдань, які сприяють збагаченню словника, розвитку зв'язного мовлення дітей, покращують фонематичне сприйняття тощо.

Метод біоенергопластики - нетрадиційний метод в логопедичній роботі з дітьми із тяжкими порушеннями мовлення. Біоенергопластика - це з'єднання рухів артикуляційного апарату з рухами кістей рук, які допомагають активізувати природний розподіл біоенергії в організмі. Це надає надзвичайно благотворний вплив на активізацію інтелектуальної діяльності дітей, розвиває координацію рухів і дрібну моторику.

В роботі з дітьми, які мають важкі мовленнєві порушення важливо активно використовувати різні види масажу. Логопедичний масаж масаж м'язів периферичного мовного апарату допомагає нормалізувати м'язовий тонус і тим самим підготувати м'язи до виконання складних рухів, необхідних при артикуляції звуків. Самомасаж - це масаж, що виконується самими дітьми (підлітком або дорослим), страждаючим мовною патологією. Самомасаж є засобом, доповнюючим дію основного масажу, який виконується логопедом. Метою логопедичного самомасажу є в першу чергу стимуляція кинестетичних відчуттів м'язів, що беруть участь в роботі периферичного мовного апарату, а також певною мірою і нормалізація м'язового тонусу даних м'язів.

ПАЛЬЧИКОВИЙ МАСАЖ

- масаж долонь кам'яними, металевими чи стікляними різнокольоровими кульками;

- прищіпковий масаж;

- масаж горіхами, каштанами;

- масаж шестигранними олівцями;

- масаж зондами, зондозамінниками;

Великої популярності набула Су-Джок терапія, яка була розроблена в Японії японським вченим Йосиро Цуцумі. В їі основі лежить уявлення про розташування на кистях рук і стопах ніг основної системи всіх внутрішніх органів і відповідних частин тіла. Руки і стопи - це ніби людина в мініатюрі, а вухо, за формою, нагадує людський ембріон. Визначивши відповідні точки на ногах і руках, можна здійснювати лікувальний вплив на хворий орган.

Останнім часом психологи, логопеди пропонують використовувати такий спосіб розвитку дитини, як Сендплей (пісочна терапія). Ігри 3 
піском розвивають тактильно- кінетичну чуттєвість і дрібну моторику рук, стабілізують емоційний стан, долають страхи, допомагають долати комплекс «поганого художника», вдосконалюють координацію, сприяють засвоєнню навичок звуко-складового аналізу та синтезу, розвивають фонематичний слух і сприйняття, сприяють розвитку зв'язного мовлення. 3 кожним роком особливої популярності набирає використання арт-терапії.

Види арт-терапій:

- музикотерапія (вокалотерапія, гра на музичних інструментах);

- кінезіотерапія (танцтерапія, тілесно-орієнтована терапія, логоритміка,психогімнастика);

- казкотерапія;

- мнемотехніка;

- креативна ігротерапия (пісочна терапія).

Музикотерапія - це ліки, які слухають. Легка спокійна музика під час корекційних занять заспокійливо діє на нервову систему, приводить в рівновагу процеси збудження і гальмування.

Вокалотерапія - це унікальний інструмент зцілення, що подарувала людині сама природа. Вокальна діяльність - найліпша форма дихальної гімнастики, що сприяє вентиляції та розвитку легенів.

Хромотерапія - це метод психологічного лікування 3 метою розслаблення, зняття стресів, підняття настрою та тонусу за допомогою кольорів.

Імаготерапія - театралізація, включає в себе: лялькотерапію, казкотерапію.

Казкотерапія - це інтеграційна діяльність, в якій створюються дії уявних ситуацій, які пов'язуються з реальним життям, спрямованих на активну участь у процесі, регулювання дитиною власних емоційних станів, самостійність, творчість.

Сміхотерапія - лікування позитивними емоціями. Сміх стимулює в організмі дитини нейтралізацію деструктивних і негативних програм, посилює утворення ендорфінів - «гормонів щастя», підтримку життєвих сил і фізичної активності, миттєве насичення енергією і бадьорістю, покращує роботу центральної нервової системи.

Кріотерапія- одна із сучасних нетрадиційних методик корекційної педагогіки, що полягає у використанні ігор з льодом. Розвиває моторні центри кори головного мозку, розвиває тактильну чутливість, поліпшує мовні навички, поліпшує артикуляційну моторику. Дозований вплив холоду на нервові закінчення має благотворні властивості. Ефект заснований на зміні діяльності судин - первинний спазм дрібних артерій поступається місцем вираженому розширенню (від холоду - скорочення 206 
м'язів, а від тепла - розслаблення), що значно підсилює приплив крові до місця впливу, що сприяє поліпшенню живлення тканин, а в кору головного мозку подаються спрямовані сигнали, отже, краще розвивається рухова зона.

ТІЛЕСНООРІЕНТОВАНІ ТЕХНІКИ: розтяжки - чергування напруги і розслаблення в різних частинах тіла, нормалізують гіпертонус і гіпотонус м'язів; вправи для релаксації - сприяють розслабленню, самоспостереженню, спогадам подій і відчуттів, що є єдиним процесом; дихальні вправи - покращують ритміку організму, розвивають самоконтроль і довільність.

КІНЕЗІОЛОГІЧНІ ВПРАВИ- комплекс рухів, які дозволяють активізувати міжпівкулеву дію: розвивають мозолисте тіло, покращують мисленнєву діяльність, сприяють покращенню роботи вищих психічних функцій.

\section{MHEMOTEXHIKA}

Мнемотехніка в перекладі з грецького - мистецтво запам'ятовування, технологія розвитку пам'яті. Це система методів і прийомів, що забезпечує успішне і ефективне запам'ятовування інформації. Будь-яку розповідь, казку, прислів'я, вірш можна «записати», використовуючи картинки або символічні знаки. Дивлячись на ці схеми, дитя відтворює отриману інформацію. Схеми служать зоровим планом, що допомагає дитині відтворити почуте.

Висновки: Таким чином, варіативність використання інноваційних технологій в корекційно-розвивальному процесі дозволяє збільшити ефективність логопедичної роботи 3 усунення порушень мовлення. Використання нетрадиційних технологій на заняттях стимулює зацікавленість дітей до мовлення, спонукає до кращого засвоєння вивченого матеріалу, урізноманітнює прийоми і методи корекційного впливу.

\section{Література:}

1. Акименко В.M. Развивающие технологии в логопедии. Ростов н/Д; изд. Феникс, 2011.

2. Андросова В. М. Використання інноваційних технологій в роботі 3 дітьми-логопатами старшого дошкільного віку для корекції вад звуковимови / В. М. Андросова // Розкажіть онуку. - 2004. - № 10-11.

3. Галущенко B.I. Особливості формування просодичного компонента мовлення у дітей зі стертою дизартрією: дис. ... канд. пед. наук: спец. 13.00.03. - О., 2012. - С.247. 
4. Гаркуша Ю.Ф., Черлина Н.А., Манина Е.В. Новые информационные технологии в логопедической работе. // Логопед. 2004. - № 2.

5. Елсакова А. Н., Лисовская Н. Н., Соколова И. В. Использование инновационных технологий в работе учителя-логопеда. // Педагогика: традиции и инновации: материалы $\mathrm{V}$ междунар. науч. конф. (г. Челябинск, июнь 2014 г.). -- Челябинск: Два комсомольца, 2014. C. 33-34.

6. Зинкевич-Евстигнеева Т.Д. Практикум по сказкотерапии / Зинкевич-Евстигнеева Т.Д. - СПб.: Речь, 2013. - 320с.

7. Логопсихологія: навч. посіб. / С. Ю. Конопляста, Т. В. Сак ; за ред. М. К. Шеремет. - К.: Знання, 2010. - 293 с.

DOI https://doi.org/10.30525/978-9934-26-173-2-57

\title{
ОСОБЛИВОСТІ ПОБУДОВИ СОЦІАЛЬНОЇ ВЗАЄМОДІї ДІТЬМИ МОЛОДШОГО ШКІЛЬНОГО ВІКУ З ПОРУШЕННЯМИ ІНТЕЛЕКТУАЛЬНОГО РОЗВИТКУ
}

\author{
Старинська О. В. \\ кандидат психологічних наук, \\ доиент кафедри прикладної психології та логопедї \\ Бердянський державний педагогічний університет \\ Кривунь О. В. \\ директор Бердянської міської гімназї № 3 «Сузір’я» Бердянської \\ міської ради Запорізької області \\ м. Бердянськ, Запорізька область, Україна
}

В процесі навчання, розвитку та виховання індивід накопичує i засвоює соціальний досвід, необхідний для успішної взаємодії 3 оточуючими, що сприяє формуванню і розкриттю його особистості. Але життя і активність людини в соціумі були б неможливі без виникнення певних суб' єктивних зв'язків між членами суспільства, що об'єктивно відбиваються в способах і характері взаємовпливів, які здійснюються людьми один на одного в процесі спільної діяльності і спілкування.

Актуальним завдання сьогодення $\epsilon$ розвиток навичок соціальної взаємодії у дітей 3 особливими освітніми потребами, що $є$ найважливішим фактором соціалізації дитини і компенсації порушень в іiі 